\title{
The Flame Characteristics of Diesel Fuel Blend with Kepuh (Sterculia foetida) Biodiesel
}

\author{
Dani Hari Tunggal Prasetiyo ${ }^{1}$, Nasrul Ilminnafik ${ }^{2 *}$, Salahuddin Junus ${ }^{2}$ \\ ${ }^{1}$ Postgraduate Student in Mechanical Engineering, Faculty of Engineering, University of Jember, Indonesia \\ ${ }^{2}$ Department of Mechanical Engineering, Faculty of Engineering University of Jember, Indonesia \\ *Corresponding author:nasrul.teknik@unej.ac.id
}

\begin{abstract}
Kepuh biodiesel fuel (sterculia foetida) is an alternative fuel that can be used to replace fossil fuel. Diesel fuel is performed to determine the laminar burning velocity and high flame by adding biodiesel kepuh volume of $10 \%, 20 \%, 30 \%$. The purpose of this study was to study the effect of biodiesel and the effect of bunsen burners on the laminar burning velocity and flame height. Bunsen burner is made of copper and stainless steel. Testing of flame characteristics was carried out by heating the mixture of fuel and air at a temperature of $200^{\circ} \mathrm{C}$. The purpose of heating the air is to prevent cooling when mixed with fuel. The mixture of fuel and air flowed into the mixing chamber and bunsen burner. The mixture of fuel and water flows into the mixing chamber and bunsen burner to form a fire. Flame images were recorded using a high-speed fuji film camera with a speed of $480 \mathrm{fps}$ with a resolution of 224x168. The test results were analyzed by measuring the angle and height of the flame using the freeware ImageJ program. The results of the B0 (diesel oil without the addition of biodiesel) fuel mixture test using copper bunsen burner produced a maximum laminar flame speed of $23.626 \mathrm{~cm} / \mathrm{s}$ at $\varphi=0.8$. The highest value of the B30 fuel mix flame $(30 \%$ biodiesel $+70 \%$ diesel oil) produces a maximum flame value using a stainless steel bunsen burner with a value of $25.417 \mathrm{~mm}$ at $\varphi=1.2$. The results showed that B0 in copper bunsen burner had the highest laminar burn rate. The composition of the fuel and bunsen burner affects the combustion characteristics and flame height.
\end{abstract}

Copyright (C 2019. Journal of Mechanical Engineering Science and Technology

All rights reserved

Keywords: Biodiesel, equivalent ratio, flame angle, flame height, laminar burning

\section{Introduction}

The increase in the human population is followed by the rise in energy consumption. Currently, the use of energy is more dominant in fossil energy, petroleum in particular [1]. Consumption of fossil fuel oil reduces petroleum reserves of available fossil fuels [2], [3]. Petroleum reserves are running low, and alternative energy sources that are renewable are being used, including biodiesel [4]. Biodiesel is obtained from the esterification and transesterification by converting triglycerides into methyl esters. The process of converting vegetable oil into biodiesel is simple and requires a reaction at low temperatures [5]. Biodiesel is an option to replace fossil fuels without modifying diesel engines [6].

Kepuh oil is crude oil from the seeds of the kepuh tree (Sterculia foetida). Kepuh tree seeds are not among foods that is used as staple consumption by most people [7]. The composition of kepuh oil consists of fat $(51.78 \%)$, protein $(21.61 \%)$, starch $(12.1 \%)$, sugar $(5 \%)$, cellulose $(5.51 \%)$ and ash (3.9\%) [8]. Kepuh biodiesel produces optimal performance in diesel engines and low exhaust emissions when compared to conventional fuels. Kepuh biodiesel has the potential to be produced into biodiesel as a substitute for 
fossil fuels [9]. Research on the production and nature of kepuh biodiesel has been carried out by Ong et al. (2013), and it is recommended to conduct further research on its combustion [14].

Premixed combustion research has been carried out with castor oil [1], kapok oil [3] and biogas $[10,11]$. Premixed combustion requires a stationary state because it affects the stability of the flame. The stationary state of combustion occurs when the reactant speed is equal to the speed of the flame propagation. In the premixed combustion test, the stationary combustion condition occurred at an equivalent ratio $=1$. The equivalent ratio greatly affects the speed of laminar combustion. The equivalent is a comparison of the stoichiometric air-fuel ratio (AFR) with the actual AFR [1], [13].

Premixed combustion testing using a cylinder type bunsen burner on vegetable oil biodiesel showed the laminar rate would decrease when the equivalent ratio increases until blow-off occur [13]. A test by varying the equivalent ratio and fuel showed that an increase in the equivalent ratio causes the laminar rate to decrease. The decrease is due to the equivalent ratio of the rich fuel so that the angle of flame formed is smaller and the reactant speed is low. Excessive air conditions may also cause a decrease in heat and combustion efficiency [1].

Kepuh biodiesel fuel research is often carried out on a 4-stroke 1 cylinder diesel engine with observations on emissions, fuel consumption and engine performance tests [9], [12]. However, experiments using premixed combustion on kepuh biodiesel are rarely done. Therefore, this research tries to understand the combustion characteristics of the premixed kepuh biodiesel by using an open cylinder type bunsen burner.

The bunsen burners are made of stainless steel and copper. The difference in the bunsen burner material aims to determine its effect on the characteristics of kepuh biodiesel flames. Excess air causes a decrease in the heat, so the combustion efficiency is less than optimal. Therefore, we need a combustion media that has good thermal conductivity so that heat is not wasted.

\section{Material and Methods}

The research was conducted by testing the combustion characteristics of diesel fuel blend with kepuh biodiesel. The composition of the fuel is shown in Table 1. Before researching the combustion characteristics, the kepuh biodiesel is tested to determine the calorific value (ASTM D88), density (ASTM D1298), viscosity (ASTM D3588) and (ASTM D88) flashpoints.

Table 1. Composition of diesel fuel with kepuh biodiesel fuel

\begin{tabular}{lr}
\hline Fuel & Percentage \\
\hline B0 & $100 \%$ diesel fuel $+0 \%$ kepuh biodiesel fuel \\
B10 & $90 \%$ diesel fuel $+10 \%$ kepuh biodiesel fuel \\
B20 & 80\% diesel fuel + 20\% kepuh biodiesel fuel \\
B30 & 70\% diesel fuel + 30\% kepuh biodiesel fuel \\
\hline
\end{tabular}


Figure 1 shows the test apparatus of laminar burning velocity and flame height. Fuel was supplied to bunsen burner (10 $\mathrm{mm}$ in diameter and $140 \mathrm{~mm}$ height) by a syringe pump ( $1 \mathrm{ml} / \mathrm{min}$.) through pipe heated at $200^{\circ} \mathrm{C}$. Air is supplied to bunsen burner by the composer through pipe heated at $200^{\circ} \mathrm{C}$ too. Fuel vapor and air mixing in the mixing chamber and ignited on a bunsen burner. The flame on the bunsen burner was recorded using high-speed camera $480 \mathrm{fps}$ for analysis.

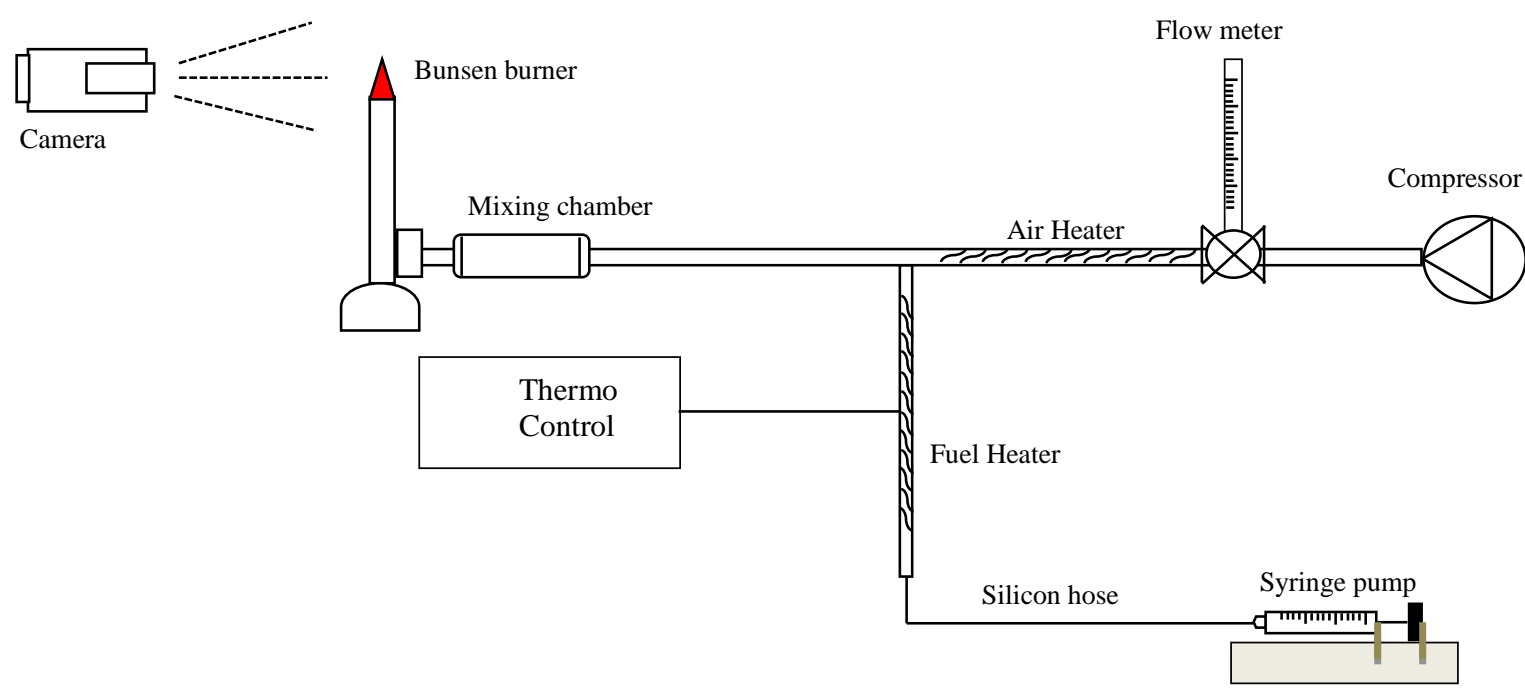

Fig. 1. Laminar burning velocity and flame height test apparatus.

The amount of air supplied in each fuel mixture composition is shown in Table 2.

Table 2. Air supply for each fuel.

\begin{tabular}{lcrrr}
\hline & B0 & B10 & B20 & B30 \\
\cline { 2 - 5 }$\varphi$ & \multicolumn{4}{c}{$\mathrm{ml} / \mathrm{min}}$. \\
\hline$\varphi 0.8$ & 3.722 & 4.056 & 3.657 & 3.565 \\
$\varphi 1.0$ & 2.977 & 3.245 & 2.925 & 2.852 \\
$\varphi 1.2$ & 2.481 & 2.704 & 2.438 & 2.377 \\
\hline
\end{tabular}

From the flame, we obtain the height (h) and the angle of flame $(\alpha)$ measured in the inner flame cone, as shown in Figure 2.
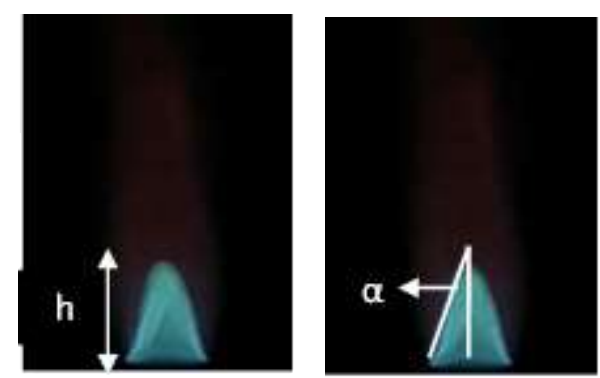

Fig. 2. Testing the height and angle of flame of biodiesel 
From the results obtained, the laminar burning velocity can be calculated using the equations (1) and (2) [3], [5].

$\mathrm{SL}=\mathrm{V} \cdot \sin \alpha$

explanation,

SL : laminar burning velocity $(\mathrm{cm} / \mathrm{s})$

$\mathrm{V}:$ reactant speed $(\mathrm{cm} / \mathrm{s})$

A : the angle of the flame

$\mathrm{V}=\frac{Q \text { Air }+Q F u e l}{A}$

explanation,

$\mathrm{V}$ : reactant speed $(\mathrm{cm} / \mathrm{s})$

$Q_{\text {air }}$ : air discharge $(\mathrm{ml} / \mathrm{min}$.)

$\mathrm{Q}_{\text {fuel }}$ : fuel discharge ( $\mathrm{ml} / \mathrm{min}$.)

A : bunsen burner cross-sectional area $\left(\mathrm{cm}^{2}\right)$

\section{Results and Discussion}

\section{Fuel Characteristic}

The characteristics of this research include the calorific value, density, viscosity and flash point as shown in Table 3. The biodiesel fuel test results have met the standard parameters of calorific value, viscosity and density so that biodiesel fuel can be used as a mixture for diesel fuel produced by PT Pertamina Indonesia, which is used now.

Table 3. Fuel characteristic

\begin{tabular}{lll}
\hline Characteristic & SNI diesel fuel* & Kepuh biodiesel** \\
\hline Calorific Value (kal/gram) & 10,602 & 11,100 \\
Density $(\mathrm{kg} / \mathrm{m} 3)$ & $815-890$ & 840 \\
Viscosity $(\mathrm{cst})$ & $2.0-6.0$ & 3.1 \\
Flashpoint $\left({ }^{\circ} \mathrm{C}\right)$ & 100 & 85 \\
\hline
\end{tabular}

Reference : *SNI diesel fuel [4]; **current research

\section{Laminar Burning Velocity (SL)}

The results of the laminar burning velocity research are shown in Table 4, 5, 6 and Figure 3, 5 and 7. The results of the study were calculated using equations (1) and (2). Equation (1) is used to calculate the value of laminar burning velocity and then to find the value of our reactant speed using equation (2).

From Figure 3, it is shown that the maximum laminar burning velocity is found at the B0 fuel blend than the others. The increase in laminar burning velocity at B0 is due to increased combustion energy in the fuel mixture. Increased combustion energy causes 
long-chain saturated fatty acids and glycerol to be very low. In addition, low glycerol is affected by air discharge. Increased airflow causes glycerol to react quickly [3]. We observe that the air discharge at B0 is higher compared to B10, B20 and B30 the comparison of air discharge shown in Table 1.

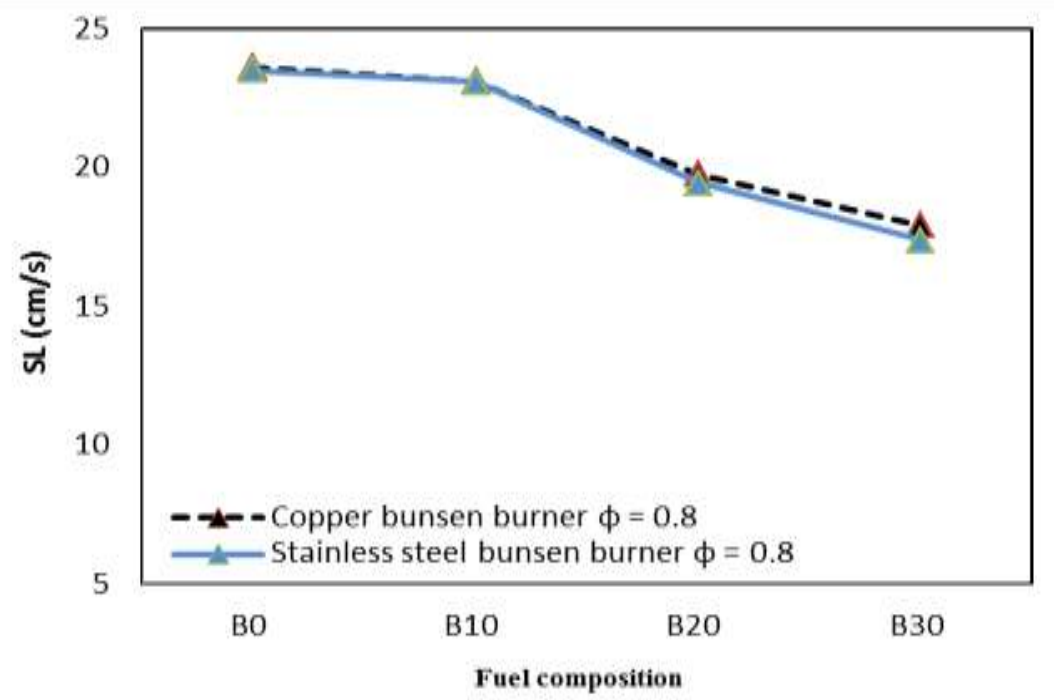

Fig. 3. The laminar burning velocity with stainless steel and copper bunsen burner at $\varphi=0.8$

Besides the lack of air discharge, the angle of flame at B10, B20 and B30 formed tends to be lower compared to the larger angle of flame of B0. In Figure 3, the angles for each of the B0, B10, B20 and B30 fuel flames in the stainless steel bunsen burner are $17.31^{\circ}, 15.54^{\circ}, 14.51^{\circ}$ and $13.37^{\circ}$, respectively. Whereas for the copper bunsen burners, the angles are $17.50,15.67^{\circ}, 14.85^{\circ}$ and $13.69^{\circ}$ respectively. This indicates that the laminar burning velocity is proportional to the flame angle [1]. Here it shows that the B0 is more combustible compared to kepuh biodiesel fuel. The laminar burning velocity values for each fuel are shown in Table 4.

Table 4. Laminar burning velocity at $\varphi=0.8$

\begin{tabular}{lcccc}
\hline \multirow{2}{*}{ Bunsen burner } & B0 & B10 & B20 & B30 \\
\cline { 2 - 5 } & \multicolumn{4}{c}{$(\mathrm{cm} / \mathrm{s})$} \\
\hline Copper bunsen burner $\varphi=0.8$ & 23.626 & 23.123 & 19.779 & 17.930 \\
Stainless steel bunsen burner $\varphi=0.8$ & 23.527 & 23.094 & 19.461 & 17.410 \\
\hline
\end{tabular}

The value of the laminar burning velocity with the copper bunsen burner is higher when compared to a stainless steel bunsen burner. Copper has a better thermal conduction emissivity so that the heat of the bunsen burner copper is spread evenly and faster; the material also tends to store heat [15]. This causes the glycerol and fatty acids to break down easily [3]. The flame image at $\varphi=0.8$ is shown in Figure 4. 


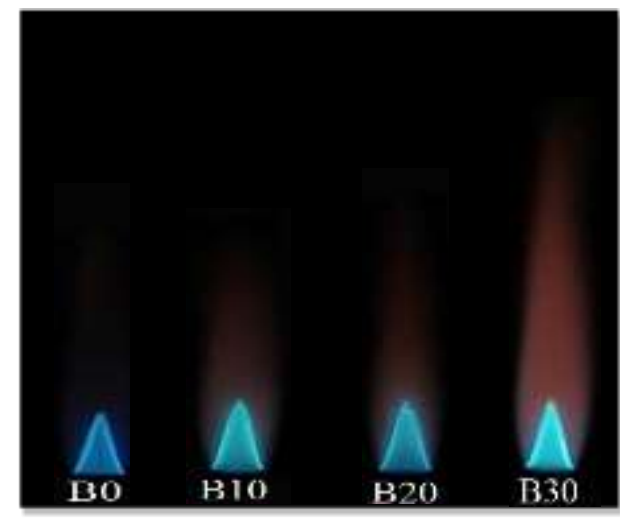

(a) Stainless steel bunsen burner

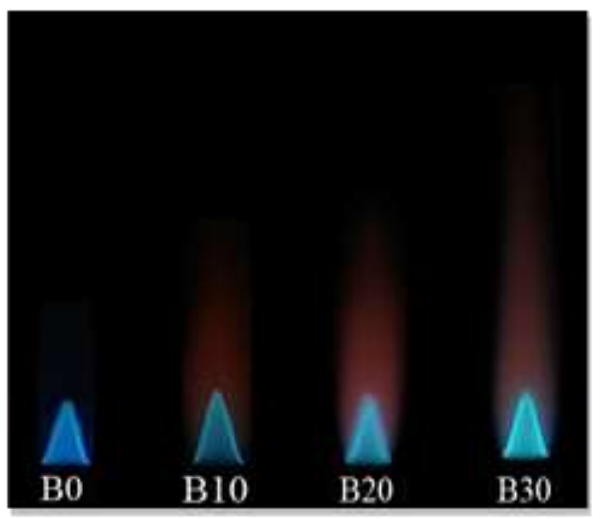

(b) Copper bunsen burner

Fig. 4. Biodiesel flame at $\varphi=0.8$

In Figure 5 it is shown the laminar burning velocity for $\varphi=1.0$ shows the decrease in laminar burning velocity when compared to $\varphi=0.8$ (in Figure 3). The reduction in laminar burning velocity is due to an increase in the equivalent ratio, which results in a decrease in the value of the flame cone angle [1]. Another factor is the decrease in reactant speed which is influenced by the increase in density and viscosity of fuel [16], [17]. The increase of density and viscosity causes the molecules to move less freely and cause the laminar burning velocity to decrease. The highest value of laminar burning velocity is from the mixture of B0 with $16.903 \mathrm{~cm} / \mathrm{s}$. This is using the copper burner as the stainless steel bunsen burner has a lower value due to stainless steel characteristic to release heat more [15].

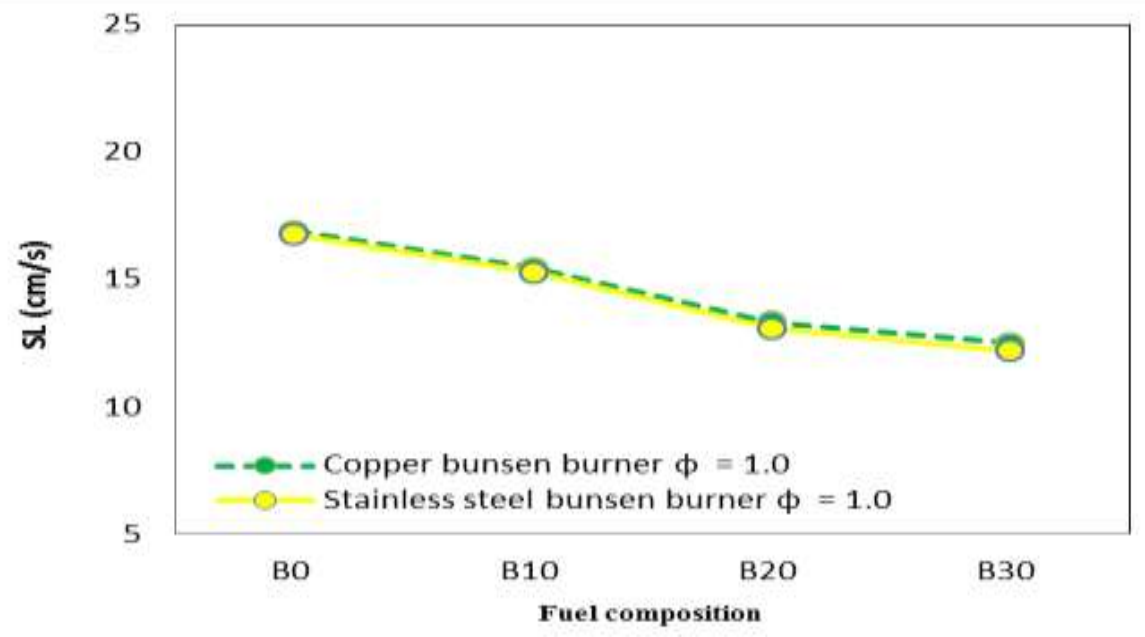

Fig. 5. The laminar burning velocity with stainless steel and copper bunsen burners at $\varphi=1.0$

The laminar combustion velocity values for each fuel at $\varphi=1.0$ are shown in Table 5 .

Table 5. Laminar burning velocity at $\varphi=1.0$

\begin{tabular}{lcccc}
\hline \multirow{2}{*}{ Bunsen burner } & B0 & B10 & B20 & B30 \\
\cline { 2 - 5 } & \multicolumn{4}{c}{$(\mathrm{cm} / \mathrm{s})$} \\
\hline Copper bunsen burner $\varphi=1.0$ & 16.903 & 15.432 & 13.311 & 12.482 \\
Stainless steel bunsen burner $\varphi=1.0$ & 16.752 & 15.281 & 13.072 & 12.187 \\
\hline
\end{tabular}


The flame image at $\varphi=1.0$ is quite stable and close to stochiometry. Pictures of the flame are shown in Figure 6.

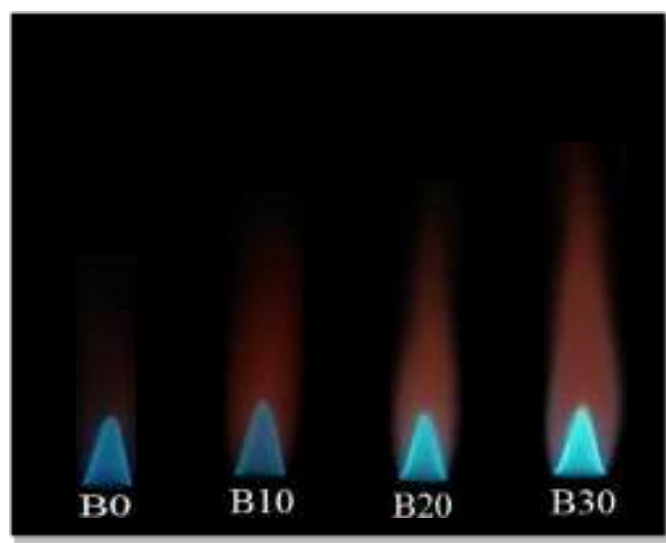

(a) Stainless steel Bunsen burner

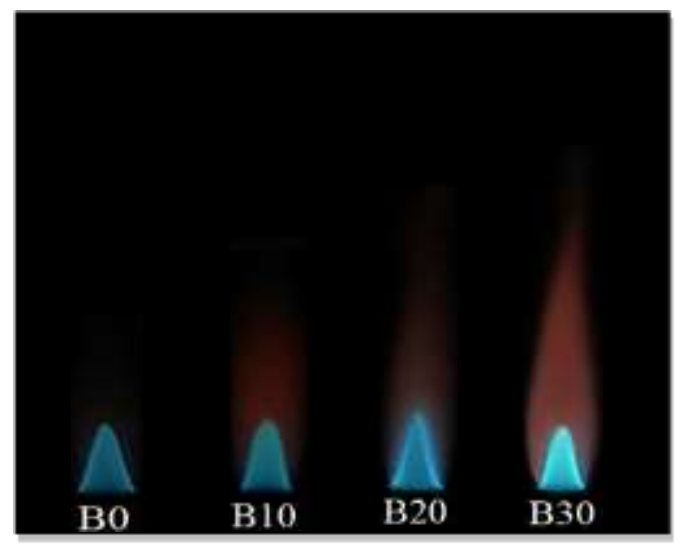

(b) Copper Bunsen burner

Fig. 6. Biodiesel flame at $\varphi=1.0$

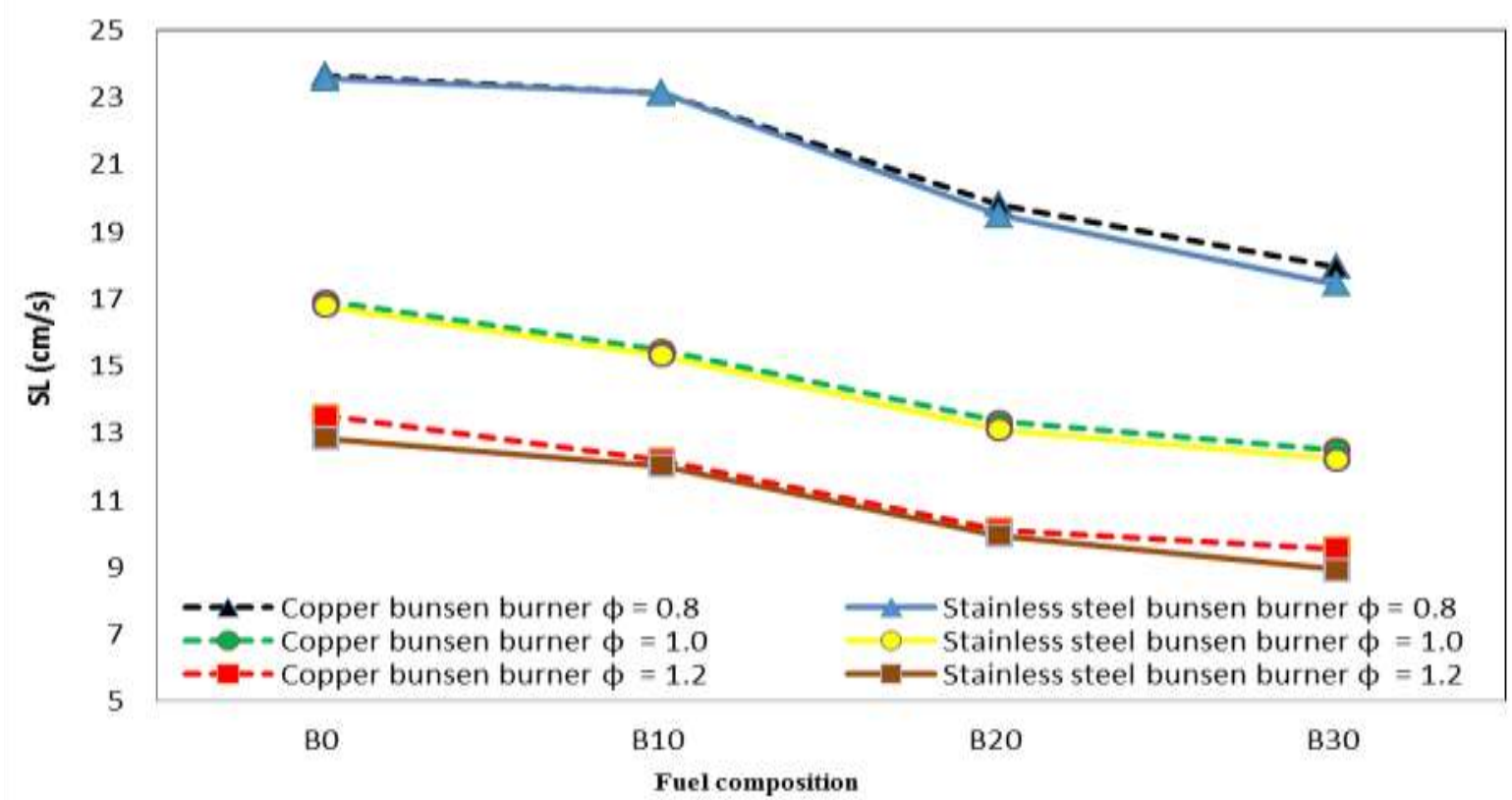

Fig. 7. Comparison of the laminar burning velocity of stainless steel and copper bunsen burners

In Figure 7, it is shown the comparison of laminar burning velocity values. The values at $\varphi=1.2$ is lower when compared to the laminar burning velocity at $\varphi=0.8$ (Figure 3 ) and $\varphi=1.0$ (Figure 5). Laminar burning velocity values at $\varphi=1.2$ is shown in Table 6 .

Table 6. Laminar burning velocity at $\varphi=1.2$

\begin{tabular}{lcccc}
\hline \multirow{2}{*}{ Bunsen burner } & B0 & B10 & B20 & B30 \\
\cline { 2 - 5 } & \multicolumn{4}{c}{$(\mathrm{cm} / \mathrm{s})$} \\
\hline Copper bunsen burner $\varphi=1.2$ & 13.493 & 12.183 & 10.092 & 9.530 \\
Stainless steel bunsen burner $\varphi=1.2$ & 12.834 & 12.007 & 9.917 & 8.903 \\
\hline
\end{tabular}


The laminar burning velocity at $\varphi=1.2$ has a fuel-rich AFR. The more it is rich in fuel, the more it causes the fuel not to oxidize as a whole. The remaining fuel reacts with outside air, causing diffusion combustion. This combustion at the end of the burner causes the flame angle to become smaller and in return, produces a lower laminar burning velocity value. Another factor is also due to the difficulty of disentangling fatty acids and glycerol at $\varphi=1.2$ [3]. The flame image at $\varphi=1.2$ is shown in Figure 8 .

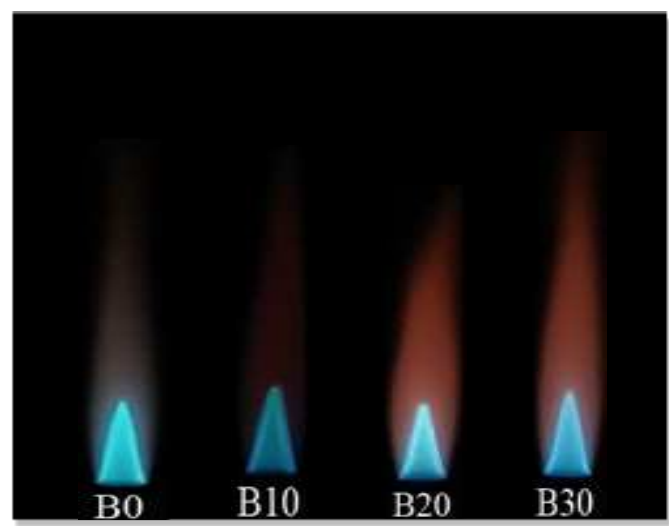

(a) Stainless steel Bunsen burner

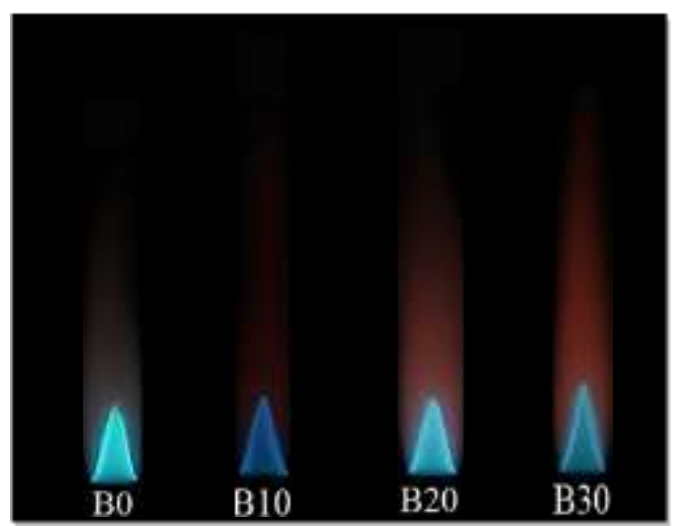

(b) Copper Bunsen burner

Fig. 8. Biodiesel flame at $\varphi=1.2$

\section{Flame Height}

The flame height in kepuh biodiesel can be observed in Table 7 and Figure 9 with stainless steel and copper bunsen burners. The height of the flame increases with the increase in equivalent ratio and fuel composition.

Table 7. Biodiesel flame height

\begin{tabular}{lcccc}
\hline Test Apparatus & $\begin{array}{c}\text { B0 } \\
(\mathrm{mm})\end{array}$ & $\begin{array}{c}\text { B10 } \\
(\mathrm{mm})\end{array}$ & $\begin{array}{c}\text { B20 } \\
(\mathrm{mm})\end{array}$ & $\begin{array}{c}\text { B30 } \\
(\mathrm{mm})\end{array}$ \\
\hline Copper bunsen burner $\varphi=0.8$ & 18.276 & 19.565 & 22.400 & 23.600 \\
Stainless steel bunsen burner $\varphi=0.8$ & 18.800 & 20.142 & 22.600 & 23.913 \\
\hline \multicolumn{5}{c}{$\varphi=1.0$} \\
\hline Copper bunsen burner $\varphi=1.0$ & 21.002 & 22.400 & 23.333 & 24.167 \\
Stainless steel bunsen burner $\varphi=1.0$ & 21.600 & 22.727 & 23.810 & 24.583 \\
\hline \multicolumn{5}{c}{$\varphi=1.2$} \\
Copper bunsen burner $\varphi=1.2$ & 22.174 & 23.043 & 24.248 & 25 \\
Stainless steel bunsen burner $\varphi=1.2$ & 22.733 & 23.821 & 24.783 & 25.417 \\
\hline
\end{tabular}

Figure 9 shows the comparison of the height of the flames. B0 fuel has a low height flame value when compared to B10, B20 and B30. The height of the flames is influenced by the characteristics of the fuel. Kepuh biodiesel has a lower flash point compared to diesel fuel. This value influences the flame ignition and fuel evaporation. A low flash point causes the flame to tend to be more stable and results in a high flame increase [13]. 


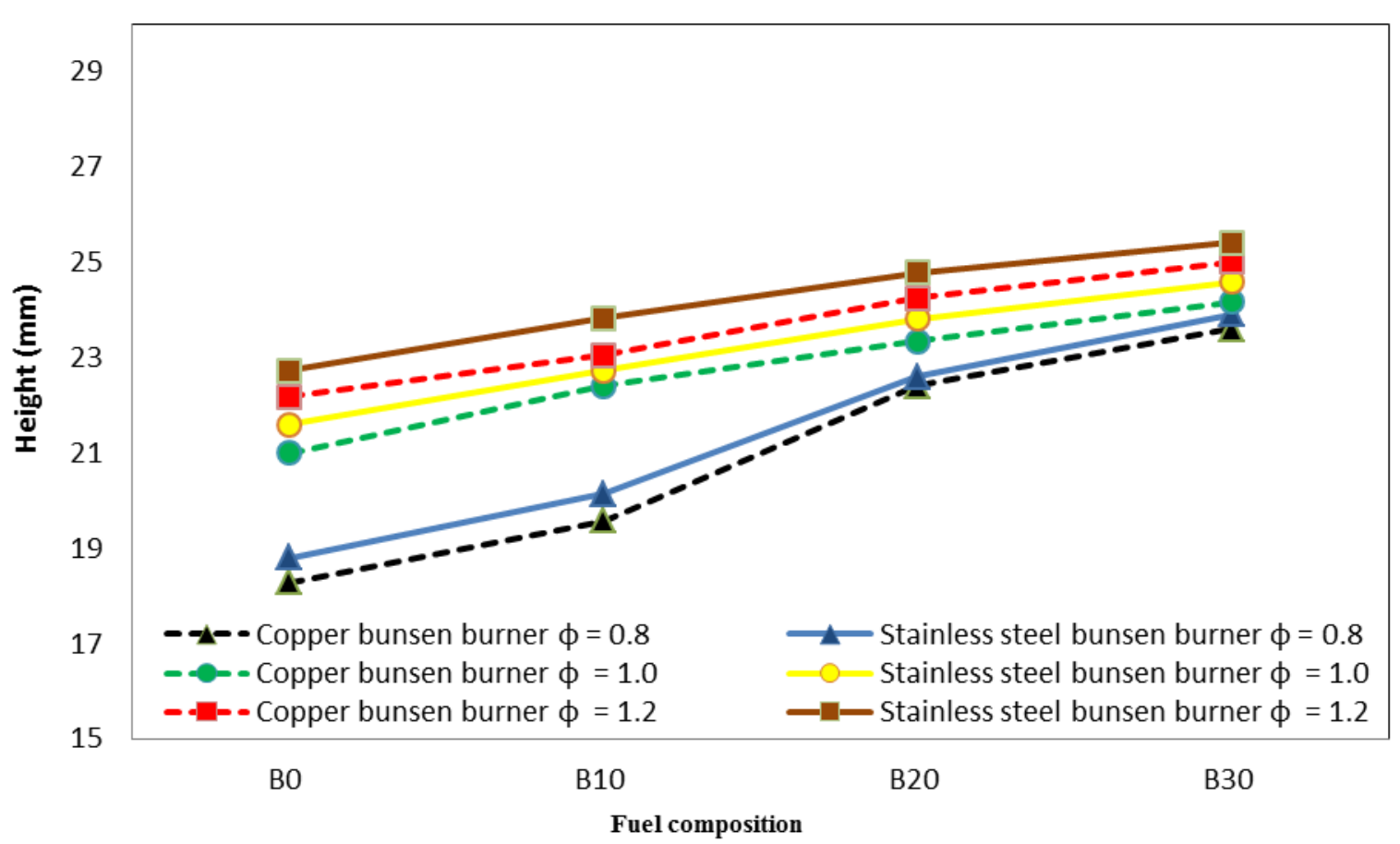

Fig. 9. Comparison of the flame height of stainless steel and copper bunsen burner

Fuel B30 at $\varphi=1.2$ produced the maximum flame height. B30 flame pattern gets higher and higher until the blow-off because of an increase in the equivalent ratio so that the flame height increases. At $\varphi=1.2$, the composition that reacts is of the rich fuel. Rich fuels react by diffusion at the tip of the bunsen burner so that the flame is pushed out and causes the flame to increase [5], [10], [13].

The B30 fuel composition with the stainless steel burner has a higher maximum flame height compared to the copper burner. The height value of B30 flame on the copper bunsen burner is $25 \mathrm{~mm}$ while the stainless steel burner is $25.417 \mathrm{~mm}$. This condition is because the stainless steel bunsen burner tends to release heat while the copper bunsen burner is more likely to store heat during the combustion reaction process. The copper bunsen burner has good thermal conductivity, and the heat of the copper burner spreads faster [15]. Higher thermal conductivity in the bunsen burner wall affects the height of the fire because this heterogeneous reaction dominates and heat in the bunsen burner wall is evenly distributed so that fuel is not pushed out which causes diffusion reactions [18], [19].

\section{Conclusion}

From this laminar kepuh biodiesel combustion study, it concludes that the value of laminar burning velocity using the cylinder bunsen burner will continue to decrease in line with the increase in equivalent ratio until blow off. The maximum laminar burning velocity is found in the $\mathrm{B} 0$ fuel mixture due to the increased combustion energy in the fuel mixture. Increased energy influence the long-chain saturated fatty acids and glycerol. At the rate of combustion of B0, fatty acids and glycerol are so low that the angle formed is large.

Increased flame height in the fuel mixture is due to an increase in the equivalent ratio. The maximum flame height was that of fuel mixture B30 with $\varphi=1.2$ on the stainless steel 
bunsen burner due to the equivalent ratio with rich fuel and oxidator not oxidizing fully and leaving remaining fuel. This remaining fuel causes diffusion combustion. During this combustion, the remaining fuel is pushed outwards until the edge of the burner. Stainless steel bunsen burners tend to have heat-releasing properties while copper bunsen burners are more likely to store heat during the combustion reaction process.

\section{References}

[1] D.B.N. Riwu, I.N.G. Wardana, dan L. Yuliati., "Kecepatan pembakaran premixed campuran minyak jarak - liquefued petroleum gas (LPG) pada circular tube burner", Jurnal Rekayasa Mesin, vol. 7, pp. 41-47, 2016.

[2] M.A.A. Banjari, L. Yuliati, dan A. A. Sonief, "Karakteristik pembakaran difusi campuran biodiesel minyak jarak pagar (Jathropha curcas L) - etanol/metanol pada mini glass tube", Jurnal Rekayasa Mesin, Vol 6, pp. 85-93, 2015.

[3] I.K.G. Wirawan, I.N.G. Wardana, R. Soenoko, and S. Wahyudi, "Premixed combustion of kapok (Ceiba pentandra) seed oil on perforated burner", IJRED, vol. 3, pp. 91-97, 2014.

[4] N. Kharis, H. Sutjahjono, H. Arbiantara, D. Setyawan, dan N. Ilminnafik, "Karakteristik biodiesel dari minyak biji randu (Ceiba pentandra) dengan proses transesterifikasi menggunakan katalis $\mathrm{NaOH”,} \mathrm{Jurnal} \mathrm{Energi} \mathrm{dan} \mathrm{Manufaktur,} \mathrm{vol.}$ 12, pp. 37-40, 2019.

[5] H. Bachtiar, B. A. Fachri, and N. Ilminnafik, "Flame characteristics of diffusion of calophyllum inophyllum methyl ester on mini glass tube", Akademia Baru., vol. 57, pp.40-47, 2019.

[6] Misbachudin., L. Yuliati, and O. Novareza, "Pengaruh persentase biodiesel minyak nyamplung-solar terhadap karakteristik pembakaran droplet”, Jurnal Rekayasa Mesin, vol. 8, pp. 9-14, 2017.

[7] A.S. Silitonga, H.C. Ong, H.H. Masjuki, T.M.I. Mahlia and W.T. Chong., "Production of biodiesel from Sterculia foetida and its process optimization", Fuel, vol. 111, pp 478-484, 2013.

[8] V. Rao, Ramesh S, and Anil Kumar S., "Study of C I engine performance with diesel - biodiesel (Sterculia foetida) blend as fuel", International Journal of Trend in Research and Development, vol. 2, pp. 76-79, 2015.

[9] M.S. Kavitha and S. Murugavelh, "Optimization and transesterification of sterculia oil: Assessment of engine performance, emission and combustion analysis", Journal of Cleaner Production, vol. 234, pp. 1192-1209, 2019.

[10] H.S. Zhen, C.W. Leung., C.S. Cheung and Z.H. Huang., "Characterization of biogashydrogen premixed flames using Bunsen burner", International Journal of Hydrogen Energy, vol. 39, pp. 13292 - 13299, 2014. 
[11] D.S. Listyadi, I. B. Erawan, and N. Ilminnafik, "Analysis of characteristic of combustion flame from biogas fuel mixed with butane", IJCAR, vol. 7, pp. 1228412287, 2018.

[12] P.P. Sethusundaram, M.Vijayakumar., and N. Prasanna, "Effect of Sterculia foetida biodiesel on single cylinder four stroke diesel engine performance and emission", Journal of Advances in Chemistry, vol 12, pp. 4614 - 4621, 2016.

[13] S. B. L. Muhaya, ING. Wardana, dan D. Widhiyanuriyawan, "Pembakaran premixed minyak nabati pada bunsen burner type silinder", Jurnal Rekayasa Mesin, vol. 6, pp. 45-50, 2015.

[14] H.C. Ong, A.S. Silitonga, H.H. Masjuki, T.M.I. Mahlia and W.T. Chong., "Production and comparative fuel properties of biodiesel from non-edible oils: Jatropha curcas, Sterculia foetida and Ceiba pentandra", Energy Conversion and Management, vol. 73, pp. 245-255, 2013.

[15] J.Wan and A. Fan., "Effect of solid material on the blow-off limit of $\mathrm{CH}_{4} /$ air flames in a micro combustor with a plate flame holder and preheating channels", Energy Conversion and Management, vol. 101, pp. 552-560, 2015.

[16] L. Mustiadi, "Karakteristik laju pembakaran minyak jarak pagar dengan penambahan partikel karbon bio", Senaspro, pp. 325-329, 2016.

[17] S. Sukarni, P. Partono, D. Krisdianto, and R. Wulandari, "Effect of magnetic field on diesel engine power fuelled with jatropha-diesel oil", Journal of Mechanical Engineering Science and Technology, vol. 1, pp. 44-48, 2017.

[18] Y. Yan, H. Wang, W. Pan, T L. Zhang, L. Li, Z. Yang, and C. Lin, "Numerical study of effect of wall parameters on catalytic combustion characteristics of $\mathrm{CH} 4 /$ air in a heat recirculation micro-combustor", Energy Conversion and Management, vol. 118, pp. 474-484, 2016.

[19] J. Zhou, Y. Wang, W. Yang, J. Liu, Z. Wang, and K. Cen, "Combustion of hydrogen-air in catalytic micro-combustors made of different material", Energy Conversion and Management, vol. 34, pp. 3535-3545, 2009. 